\title{
Effectiveness of Cooking Methods on Presence of Food Borne Pathogens in Chicken based Meat Products
}

\author{
Mahantesh F. Meti* and V. Appa Rao \\ Department of Livestock Products Technology (Meat Science), Madras Veterinary College, \\ TANUVAS, Chennai 600 007, Tamil Nadu, India \\ *Corresponding author
}

\section{A B S T R A C T}

\begin{tabular}{|l|}
\hline Ke y w or d s \\
Artificial \\
contamination, \\
Cooking effect, \\
Core temperature, \\
$\begin{array}{l}\text { Fast food outlets, } \\
\text { Street food vendors. }\end{array}$ \\
\hline Article Info \\
\hline $\begin{array}{l}\text { Accepted: } \\
\text { 04 September 2017 } \\
\text { Available Online: } \\
\text { 10 October 2017 }\end{array}$ \\
\hline
\end{tabular}

The food borne diseases are often unnoticed and source of infection is always not confirmative. The consumption of street and fast food has been popularising in developing country like India. The present study was to taken up to assess the effect of different cooking procedures followed by street food vendors and fast food outlets in Chennai city, India. The food borne pathogens viz., Escherichia coli, Salmonella spp, Staphylococcus aureus and Campylobacter jejuni studied by artificially inoculating in chicken meat preparation at level of $100 \mathrm{cfu} / \mathrm{g}$ and $1000 \mathrm{cfu} / \mathrm{g}$. The different chicken based meat preparation and cooking practice followed were viz. pan frying for chicken 65 and chilly chicken, oven cooking for tandoori chicken and electric grilling in grilled chicken. The core temperature of $82.8^{\circ} \mathrm{C}, 83.8^{\circ} \mathrm{C}, 74.3^{\circ} \mathrm{C}$ and $75.3^{\circ} \mathrm{C}$ was achieved in chicken 65 , chilly chicken, tandoori chicken and grilled chicken, respectively. The different cooking methods resulted in complete elimination (absent in $25 \mathrm{~g}$ of product) of all food borne pathogens viz., Escherichia coli, Salmonella spp, Staphylococcus aureus and Campylobacter jejuni at both $100 \mathrm{cfu} / \mathrm{g}$ and $1000 \mathrm{cfu} / \mathrm{g}$ and reaching satisfactory core temperature of $72^{\circ} \mathrm{C}$ in above. Thus, cooking procedures by street food vendors and fast food outlets in Indian condition often produce safe chicken products.

\section{Introduction}

Food-borne diseases defined by World Health Organisation as "diseases of infectious or toxic origin caused by consumption of food or water" (WHO, 1988). The most common pathogenic microorganisms associated with food borne outbreaks are Escherichia coli, Salmonella spp, Staphylococcus aureus, Campylobacter jejuni and Listeria spp. These foods borne diseases are one of the leading cause for major human suffering (mortality and morbidity) and economic loss worldwide (CDC, 2017). The poultry and poultry products are often contaminated with potential pathogenic bacteria if proper hygienic practises are not followed at during processing, preparation and storage of chicken products, subsequently they become significant source of food borne diseases. In Indian scenario the major cause for food borne diseases are due to poultry meat and poultry products (Antony et al., 2009). Dharshana et al., (2014) reviewed on status of bacterial pathogens in chicken meat and quoted that till 2012, a total of 2030 chicken meat samples were analyzed by different researchers in different parts of India of which 
759 samples were found positive for certain pathogenic microorganisms, of which the prevalence of different food borne pathogens like Salmonella spp (33.16\%), Campylobacter spp $(95 \%)$ Escherichia coli (70.22\%), Clostridia spp (13.88\%), Listeria monocytogenes (15\%) and Staphylococcus aureus $(11.25 \%)$ are reported.

In India chicken meat is the major source of animal protein when compared to other meats due to its relative low price, ease of availability and no religious taboos associated with its consumption. The broiler meat production in India is expected to increase to 4.5 million tonnes on par with increasing demand from growing population. Along with the rise in the demand for chicken meat, there has been increase in popularity for processed chicken meat products at retail fast food outlets which is growing at the rate of $15-20 \%$ per year.

Food borne outbreaks occur mainly from households or domestic kitchen of consumers $(39.7 \%)$ and restaurants, cafes, pubs and hotels (23.9\%), (EFSA and ECDC, 2014). The large part of food borne outbreaks or food poisoning is due to unhygienic and unscrupulous practices by food handlers during preparation (Sampers et al., 2012). In general, at least $30 \%$ of consumers under cook meat (Phang and Bruhn, 2011). However, $50 \%-88 \%$ think subjective evaluation is acceptable to determine end of cooking process and $93 \%$ of consumers rely on visual indicator to determine doneness of meat (Redmond and Griffith, 2003). Hence there is a necessity to define appropriate measures to prevent food borne outbreaks, as chicken meat and products often serve as carrier for food borne pathogens. In order to prevent food borne diseases, different practises followed in post processing are adequate cooking, safe handling and maintaining cold chain.
When meat is subjected to the core temperature of $70^{\circ} \mathrm{C}$ for 2 minutes or subjected to heat treatment equivalent to 2 min at $70^{\circ} \mathrm{C}$, it will accomplish substantial inactivation of $6 \mathrm{log}$ reduction of pathogens and renders meat safe to eat (ACMSF, 2007). The cooking is an important process in eliminating food borne pathogen from ground meat products and thought to be one of the critical point in meat processing to prevent the pathogen in ready to meat products (Murphy et al., 2004). Few studies have been carried out to assess the effect of different cooking method on pathogens in meat products, Sampers et al., (2012) reported that when burgers naturally contaminated or artificially inoculated with Campylobacter spp. later subjected to consumer based frying, their levels declined after 2 minutes once temperature attained $38^{\circ} \mathrm{C}$ and dropped below detectable level after 4 minutes when temperature recorded was $57^{0} \mathrm{C}$. Roccato et al., (2014) assessed the effect of different cooking method on (grilling, frying and baking) presence of Salmonella typhimurium DT104 in artificially inoculated five different poultry based meat preparations (burgers, sausages, ready-to-cook kebabs, quail roulades and extruded roulades) and reported that cooking process eliminated Salmonella typhimurium at 10 and $100 \mathrm{CFU} / \mathrm{g}$ contamination levels but not at 1000CFU/g inoculated levels completely.

The purpose of this study was to simulate and assess the effect of different cooking methods (pan frying, oven cooking, grilling) practised by street food vendors and fast food outlets in Chennai, India, on chicken meat based preparations for presence of food borne pathogens viz., Salmonella spp., Escherichia coli, Staphylococcus aureus and Campylobacter jejuniand to arrive at optimal cooking time temperature combination to eliminate food borne pathogens in above cooking methods. 


\section{Materials and Methods}

\section{Reference strains used for simulation study}

The present study involves four different reference bacterial strains viz., Staphylococcus aureus (MTCC 3162), Salmonella spp. (MTCC 1160), Escherichia coli(MTCC 42) and Campylobacter jejuni (ATCC) which were used to assess the effect of cooking method on in house prepared simulated chicken products.

\section{Preparations of meat products}

In the present study four different chicken products (Chicken 65, Chilly chicken, Chicken tandoori and Grilled chicken) were prepared as per recipe standardized in the Department of Livestock Products Technology (Meat Science) and cooking procedure followed was as per the common practices of street food vendors and fast food outlets. The chicken meat for the present study was procured from local retail meat outlets and was brought to Department Of Livestock Products Technology (Meat Science), hygienically in a sterile container by maintaining cold chain with ice packs. The ingredients used for different chicken products preparation were procured from local super market.

The formulation and material composition involved in preparation of four different products are given in table 1 . The chicken 65 and chilly chicken were prepared as per the recipe mentioned in table 1 and cooking was done by method of pan frying. Tandoori chicken and grilled chicken were prepared by marinating the chicken pieces in the marinade (as mentioned in table 1 at refrigeration $\left(4 \pm 1^{0} \mathrm{C}\right)$ temperature for 6hours and oven cooked for tandoori chicken and electrical grilling for grilled chicken.

\section{Assessment of initial quality of chicken meat}

The total viable count (TVC) and presence of different food borne pathogens Staphylococcus aureus, Escherichia coli, Salmonella spp. and Campylobacter jejuni in fresh meat sample were assessed to know the initial quality of meat procured.

\section{Total viable count}

For determination of microbial counts, $10 \mathrm{~g}$ of sample was homogenized with $90 \mathrm{ml}$ of $0.1 \%$ sterile peptone water. Serial 10 -fold dilutions were prepared by diluting $1 \mathrm{ml}$ of homogenate in $9 \mathrm{ml}$ of $0.1 \%$ peptone water.

Appropriate serial dilutions were plated in duplicates (Pour plate method) with plate count agar for total plate count (TPC) and plates were incubated at $37^{\circ} \mathrm{C}$ for 48 hours for TPC (ICMSF, 1983).

\section{Cultural techniques for detection of food borne pathogen}

The cultural methods for detection of different food borne pathogens like Staphylococcus aureus, Escherichia coli, Salmonella spp. and Campylobacter jejuni were followed as per International organization for standardization (ISO) procedures. For detection of Staphylococcus aureus ISO standard 6888/1:1999 was followed, Baird-Parker agar medium (Himedia, Mumbai) was used for plating. For detection of Escherichia coli ISO standard 16654:2001 was followed, eosin methylene blue (EMB) agar (Himedia, Mumbai) was used for plating. For detection Salmonella spp. ISO standard (ISO 6579:2002) was followed, Xylose lysine deoxycholate (XLD) agar (Himedia, Mumbai) was used for plating. For detection of Campylobacter jejuni ISO standard 10272:1995 was followed, Blood 
Free Campylobacter selective agar was used for plating.

\section{PCR methods for identification of food borne pathogens}

Further identification was done by polymerase chain reaction with DNA extracted from overnight broth cultures of different bacterial selective broths by kit method (Quiagen $\left.{ }^{\circledR}\right)$. The primers and cyclical conditions followed were given in table 2 . The species specific simplex PCR was performed targeting invA gene for Salmonella spp., uspA gene for Escherichia coli, nuc gene for Staphylococcus aureus and flaA gene for Campylobacter jejuni respectively.

\section{Artificial contamination procedure}

A pure broth culture of Staphylococcus aureus, Escherichia coli, Salmonella spp. and Campylobacter jejuni was obtained and the optical density value was adjusted to $1.0 \mathrm{MF}$ using densicheck instrument. The broth cultures were serially diluted with phosphate buffer saline (PBS) to obtain cell density of $100 \mathrm{cfu} / \mathrm{g}$ and $1000 \mathrm{cfu} / \mathrm{g}$ on meat preparations. The inoculation procedure was based on technical guidance document on shelf-life studies for Listeria monocytogenes in ready-to-eat foods (EU, CRL, 2008). For chicken 65 , chilly chicken, tandoori chicken and grilled chicken for each inoculum level, 1 $\mathrm{ml}$ of appropriate dilution was added to $125 \mathrm{~g}$ of meat preparation and mixed thoroughly to obtain 100cfu/g and $1000 \mathrm{cfu} / \mathrm{g}$ on meat products. Both inoculum level samples were analyzed to see the presence of pathogens inoculated. The meat preparations were analyzed before and after cooking procedures.

\section{Cooking treatments: pan frying, grilling and oven cooking}

The cooking treatments in the present study involves pan frying for chicken 65 and chilly chicken, grilling for grilled chicken and oven cooking for tandoori chicken preparation. The cooking treatments were done according to visual indication or till the core temperature of $75^{\circ} \mathrm{C}$ reached indicating completion of cooking process as followed by street food vendors and fast food outlet. Optimized timetemperature combinations for cooking treatments are shown in table 3. Meat product was grilled on electrical grill by turning continuously during cooking. The pan frying was carried in a pan with $100 \mathrm{ml}$ of vegetable oil using medium heat and with regular turning during cooking. Tandoori preparation was done in electric tandoori oven. All the cooking equipment was procured from regional market (M/s prestige)

\section{Results and Discussion}

\section{Assessment of initial quality of meat}

The fresh meat sample procured were initially tested for quality and the presence of different food borne pathogens viz., Escherichia coli, Salmonella spp, Staphylococcus aureus and Campylobacter jejuni by the standard procedure. The initial quality of raw meat by total viable count was found to be 3-4 log $\mathrm{CFU} / \mathrm{g}$ indicating fair initial quality (PFA, 1956). Escherichia coli, Salmonella spp, Staphylococcus aureus and Campylobacter jejuni were not detected of the raw meat used for the study. These were in accordance with guidelines of PFA (1956).

\section{Temperature profile during product preparation}

The present study was focused on thermal inactivation of food borne pathogenic bacteria viz. Escherichia coli, Salmonella spp, Staphylococcus aureus and Campylobacter jejuni by inoculating chicken products during preparation followed by different cooking practices mimicking the street food vendors and fast food outlets. The core temperature 
during cooking was recorded using probe thermometer and results recorded were shown in table 3. It was found that time required to reach core temperature was achieved within 4-5 minutes during pan frying, measuring around $82.2^{\circ} \mathrm{C}$ to $83.3^{\circ} \mathrm{C}$ when color change was evident. Similarly, in grilling and oven cooking the core temperature was achieved by 9-10 minutes and the temperature recorded around $74-75^{\circ} \mathrm{C}$. The majority of consumers assume that under cooking of meat products represent risk factor associated with foodborne disease and that thoroughly cooking meat will decrease the risk of food poisoning and it is being reported to be one of the critical point in processing meat to prevent pathogens (Murphy et al., 2004). Most consumer know how to check doneness of meat products usually checked with help of thermometer however majority of people do not use this technique but depend on the color change and aroma (Bergsma et al., 2007; Fischer et al., 2007). The choice of cooking method by most of street food vendors, fast food outlets and house old depend on taste, palatability and texture of product.

Table.1 Recipes for different chicken products

\begin{tabular}{|c|c|c|c|c|c|}
\hline S.No. & Ingredients & Chicken 65 & Chilly chicken & Grilled chicken & Tandoori chicken \\
\hline I & Broiler meat $(\mathrm{g})$ & 125 & 125 & 125 & 125 \\
\hline 1 & Curd (ml) & $125 \mathrm{ml}$ & $125 \mathrm{ml}$ & $125 \mathrm{ml}$ & $125 \mathrm{ml}$ \\
\hline 2 & Chilli powder (g) & 1 & 1 & 2 & 2 \\
\hline 3 & Ginger and Garlic paste $(\mathrm{g})$ & 4 & 4 & 4.5 & 5 \\
\hline 3 & Turmeric powder $(\mathrm{g})$ & 0.2 & 0.2 & 0.5 & 0.5 \\
\hline 5 & Common salt(g) & 2 & 2 & 2 & 2 \\
\hline 6 & Lemon juice(ml) & 2 & 2 & 2 & 2 \\
\hline 7 & Butter(gm) & - & - & 10 & 10 \\
\hline 8 & Egg & - & Half & Half & - \\
\hline 9 & Dried coriander and Cumin powder $(\mathrm{g})$ & 2 & 2 & 1 & 1 \\
\hline 10 & Onion $(\mathrm{g})$ & 2.5 & - & 2 & - \\
\hline
\end{tabular}

Table.2 Primers and cyclical conditions for food borne pathogens

\begin{tabular}{|c|c|c|c|c|c|}
\hline SI. No & Target gene & Primer sequence & Product size (bp) & References & Cyclical conditions \\
\hline 1. & uspA & $\begin{array}{l}\text { E. coli Forward Primer } \\
\text { 5, CCG ATA CGC TGC CAA TCA GT3, } \\
\text { E. coli Reverse Primer } \\
\text { 5, ACG CAG ACC GTA GGC CAG AT 3, }\end{array}$ & 884 & $\begin{array}{l}\text { Chen and } \\
\text { Griffths } \\
\text { (1998) }\end{array}$ & $\begin{array}{l}\text { i. } 94^{\circ} \mathrm{C} \text { for } 5 \text { minutes } \\
\text { ii. } 94^{\circ} \mathrm{C} \text { for } 1 \text { minute } \\
\text { iii. } 58^{\circ} \mathrm{C} \text { for } 45 \text { seconds } \\
\text { iv. } 72^{\circ} \mathrm{C} \text { for } 1 \text { minute } \\
\text { v. } 72^{\circ} \mathrm{C} \text { for } 1 \text { minute } \\
\text { (ii, iii and iv were repeated for } 34 \text { cycles) }\end{array}$ \\
\hline 2. & invA & $\begin{array}{l}\text { Salmonella spp. Forward Primer } \\
\text { 5'GTG AAA TTA TCG CCA CGT TCG GGC AA3' } \\
\text { Salmonella spp. Reverse Primer } \\
\text { 5' TCA TCG CAC CGT CAA AGG AACC 3' }\end{array}$ & 284 & $\begin{array}{l}\text { Zahraei } \\
\text { et al., (2005) }\end{array}$ & $\begin{array}{l}\text { i. } 94^{\circ} \mathrm{C} \text { for } 5 \text { minutes } \\
\text { ii. } 94^{\circ} \mathrm{C} \text { for } 1 \text { minute } \\
\text { iii. } 55^{\circ} \mathrm{C} \text { for } 1 \text { minute } \\
\text { iv. } 72^{\circ} \mathrm{C} \text { for } 2 \text { minute } \\
\text { v. } 72^{\circ} \mathrm{C} \text { for } 5 \text { minute } \\
\text { (ii, iii and iv were repeated for } 35 \text { cycles) }\end{array}$ \\
\hline 3. & Nuc & $\begin{array}{l}\text { Staphylococcus aureus Forward Primer } \\
\text { 5' GTGCTGGCATATGTATCGCAATTGT3' } \\
\text { Staphylococcus aureus Reverse Primer } \\
\text { 5' TACGCCCTTATCTGTTTGTGATGC3, }\end{array}$ & 181 & Hedge (2013) & $\begin{array}{l}\text { i. } 94^{\circ} \mathrm{C} \text { for } 5 \text { minutes } \\
\text { ii. } 94^{\circ} \mathrm{C} \text { for } 1 \text { minute } \\
\text { iii. } 58^{\circ} \mathrm{C} \text { for } 45 \text { seconds } \\
\text { iv. } 72^{\circ} \mathrm{C} \text { for } 30 \text { seconds } \\
\text { v. } 72^{\circ} \mathrm{C} \text { for } 10 \text { minute } \\
\text { (ii, iii and iv were repeated for } 29 \text { cycles) }\end{array}$ \\
\hline 4 & flaA & $\begin{array}{l}\text { Campylobacter jejuni forward primer } \\
\text { 5'TCTGCTAAGGCTCCAAGT3' } \\
\text { Campylobacter jejuni forward primer } \\
\text { 5'CTCAAGCGGCTCAAGATG3' }\end{array}$ & 367 & $\begin{array}{c}\text { Dhanalakshmi } \\
\text { (2011) }\end{array}$ & $\begin{array}{l}\text { i. } 94^{\circ} \mathrm{C} \text { for } 5 \text { minutes } \\
\text { ii. } 94^{\circ} \mathrm{C} \text { for } 1 \text { minute } \\
\text { iii. } 52^{\circ} \mathrm{C} \text { for } 45 \text { seconds } \\
\text { iv. } 72^{\circ} \mathrm{C} \text { for } 1 \text { minute } \\
\text { v. } 72^{\circ} \mathrm{C} \text { for } 10 \text { minute } \\
\text { (ii, iii and iv were repeated for } 34 \text { cycles) }\end{array}$ \\
\hline
\end{tabular}

(i- initial denaturation, ii- Denaturation, iii- Annealing, iv- Extension, v- Final extension) 
Table.3 Core temperatures of chicken products under different cooking methods

\begin{tabular}{|l|l|l|c|c|}
\hline Sl.no & \multicolumn{1}{|c|}{ Product } & \multicolumn{1}{|c|}{ Cooking method } & Cooking time (minutes) & Average temperature $\left({ }^{\circ} \mathbf{C}\right)$ \\
\hline 1 & Chicken 65 & Pan frying & 08 & $82.8 \pm 0.454$ \\
\hline 2 & Chilly chicken & Pan frying & 08 & $83.8 \pm 0.182$ \\
\hline 3 & Tandoori chicken & Oven & 15 & $74.3 \pm 0.238$ \\
\hline 4 & Grilled chicken & Grill & 15 & $75.35 \pm 0.457$ \\
\hline
\end{tabular}

Table.4 residual recovery of pathogenic bacteria at100 CFU/G and1000 CFU/G inoculum level

\begin{tabular}{|c|c|c|c|c|c|c|}
\hline \multirow[t]{2}{*}{ Sl.no } & \multirow[t]{2}{*}{ Product } & \multirow[t]{2}{*}{ After inoculation } & \multicolumn{4}{|c|}{ Recovery of food borne pathogens } \\
\hline & & & S. aureus & E. coli & C.jejuni & Salmonella spp. \\
\hline \multirow[t]{2}{*}{1} & \multirow[t]{2}{*}{ Chicken 65} & Before cooking & $2 / 2$ & $2 / 2$ & $2 / 2$ & $2 / 2$ \\
\hline & & After cooking & $0 / 2$ & $0 / 2$ & $0 / 2$ & $0 / 2$ \\
\hline \multirow[t]{2}{*}{2} & \multirow{2}{*}{$\begin{array}{l}\text { Chilly } \\
\text { chicken }\end{array}$} & Before cooking & $2 / 2$ & $2 / 2$ & $2 / 2$ & $2 / 2$ \\
\hline & & After cooking & $0 / 2$ & $0 / 2$ & $0 / 2$ & $0 / 2$ \\
\hline \multirow[t]{2}{*}{3} & \multirow{2}{*}{$\begin{array}{l}\text { Tandoori } \\
\text { chicken }\end{array}$} & Before cooking & $2 / 2$ & $2 / 2$ & $2 / 2$ & $2 / 2$ \\
\hline & & After cooking & $0 / 2$ & $0 / 2$ & $0 / 2$ & $0 / 2$ \\
\hline \multirow[t]{2}{*}{4} & \multirow{2}{*}{$\begin{array}{l}\text { Grilled } \\
\text { chicken }\end{array}$} & Before cooking & $2 / 2$ & $2 / 2$ & $2 / 2$ & $2 / 2$ \\
\hline & & After cooking & $0 / 2$ & $0 / 2$ & $0 / 2$ & $0 / 2$ \\
\hline
\end{tabular}

Fig.1 Different chicken based meat preparation

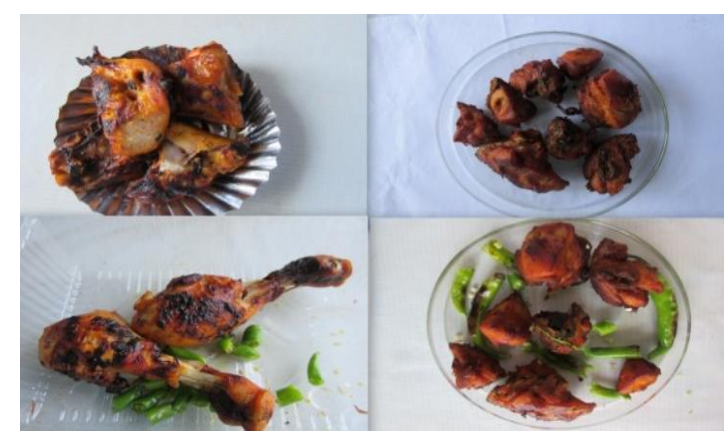

Fig.2 PCR for Escherichia coli

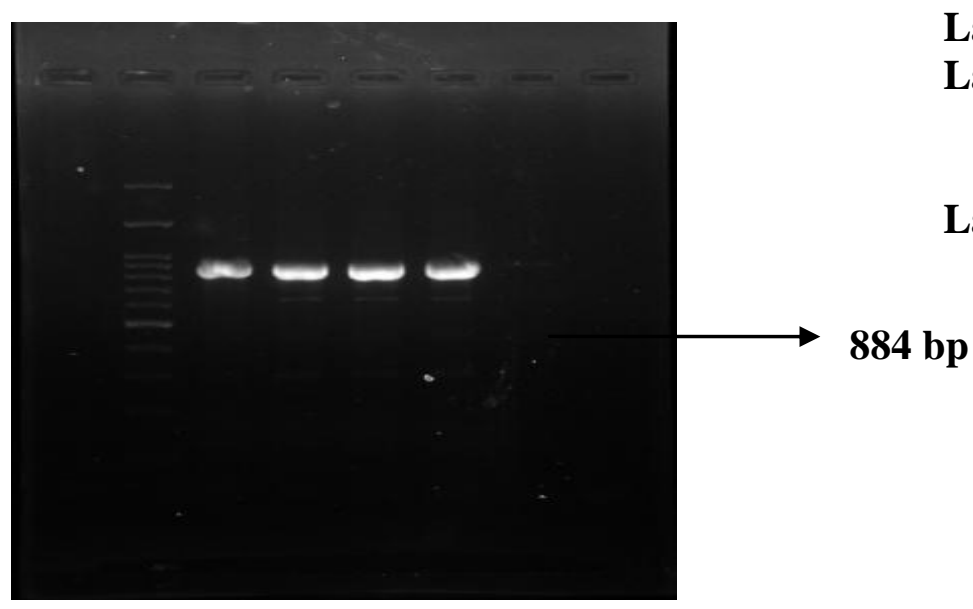

Lane M: 100 bp DNA Ladder Lane 1-4: 884 bpPCR product of uspA gene of Escherichia coli Lane 5: Negative Control 
Fig.3 PCR for Salmonella spp

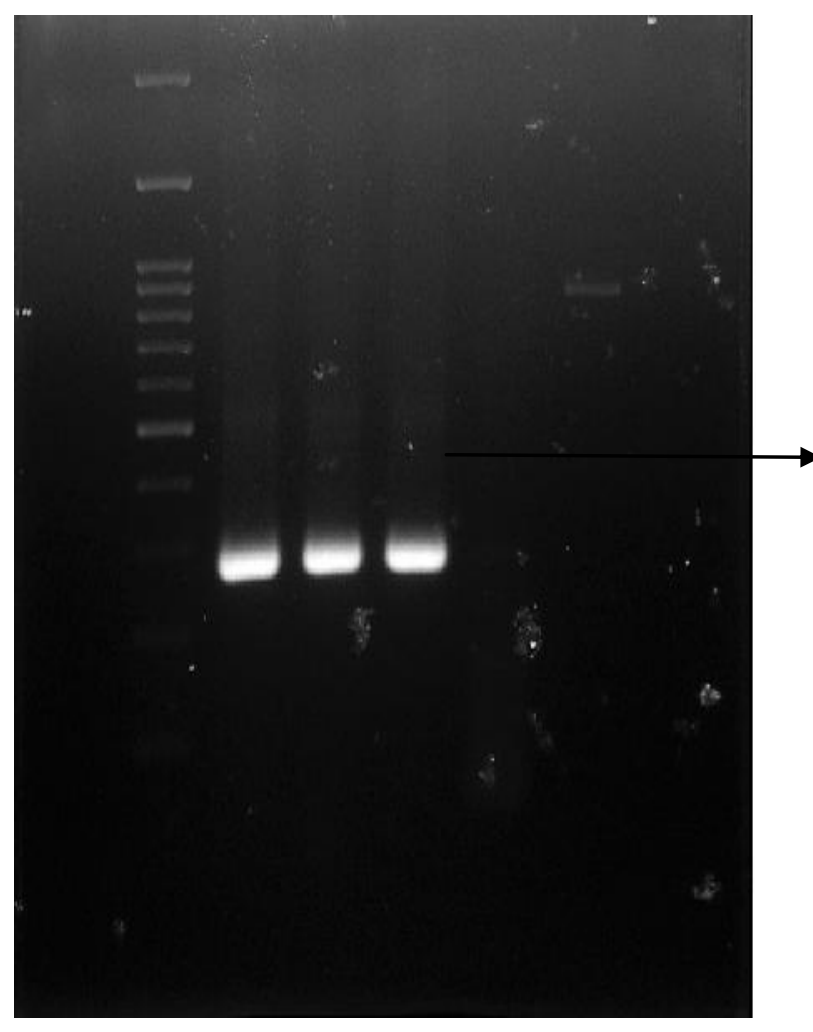

Lane M: 100 bp DNA Ladder

Lane 1-3: 284 bp PCR product of invA gene of Salmonella spp.

Lane 4: Negative Control

Fig.4 PCR for Staphylococcus aureus

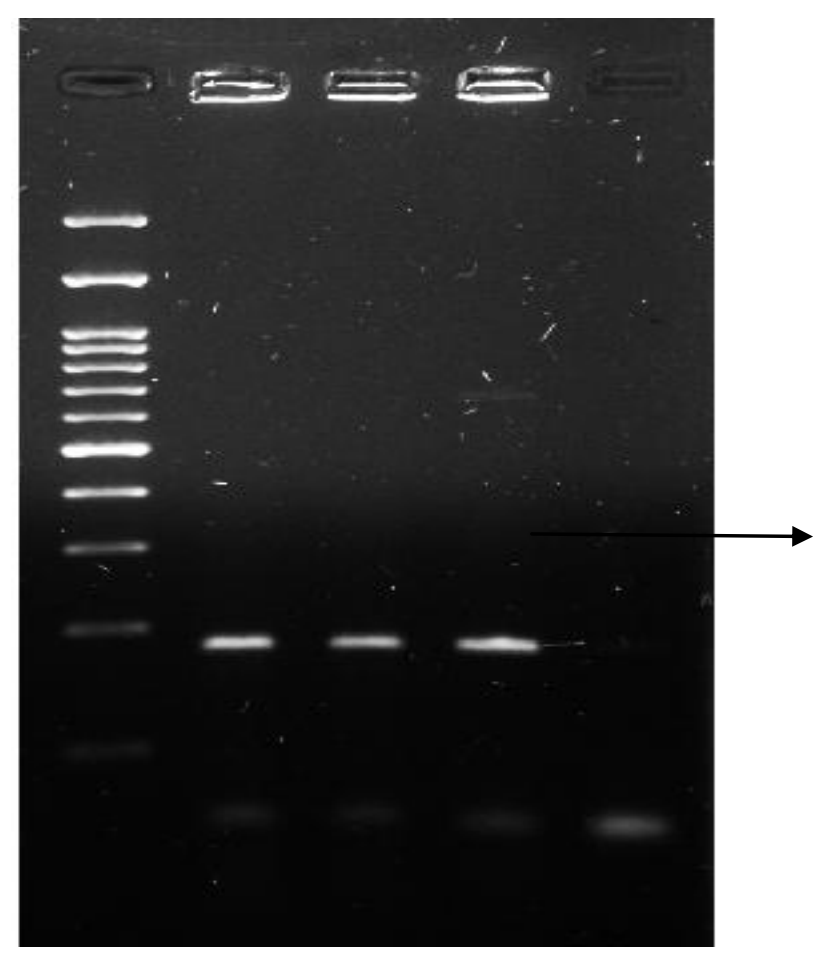

Lane M: 100bp DNA Ladder Lane1-3: 181bp PCR product of nuc gene of Staphylococcus aureus

Lane 4: Negative Control

181 bp 
Fig.5 PCR for Campylobacter jejuni

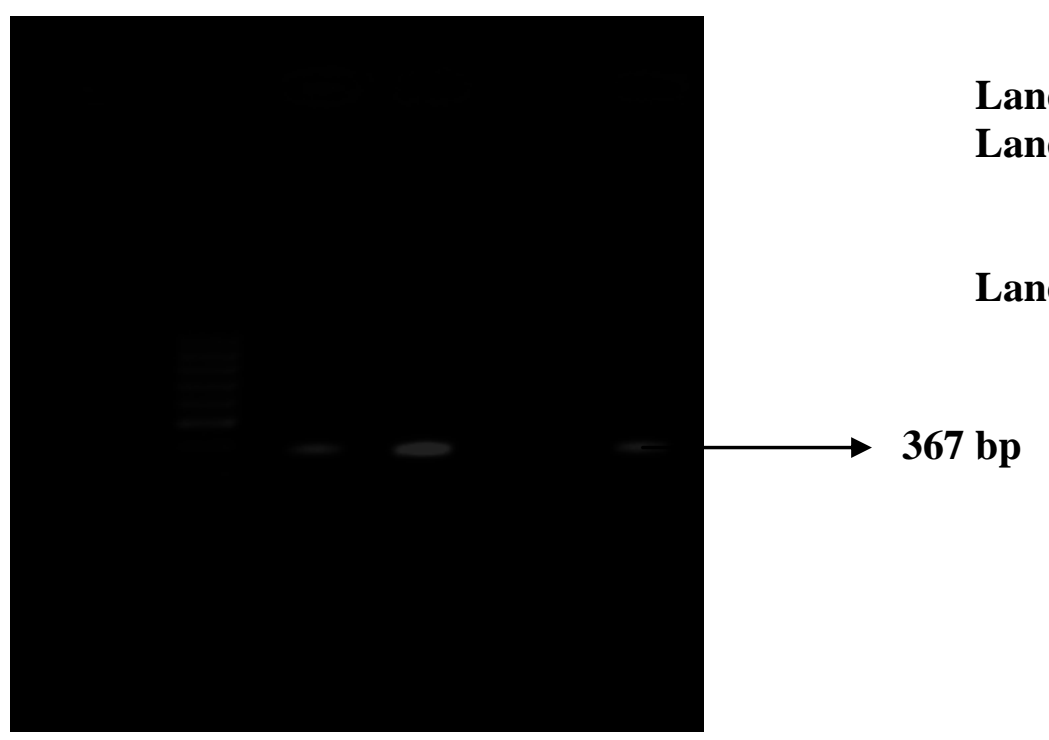

\section{Lane M: 100 bp DNA Ladder Lane 1,2,4: 367 bpPCR product of flaA gene of Campylobacter jejuni Lane 3: Negative Control}

Fig.6 Growth characteristics of bacteria on selective agars A: Baird-Parkaer agar, B: Blood free campylobacter agar base C: Eosin Methylene blue agar, D: Xylose lysine deoxy cholate agar

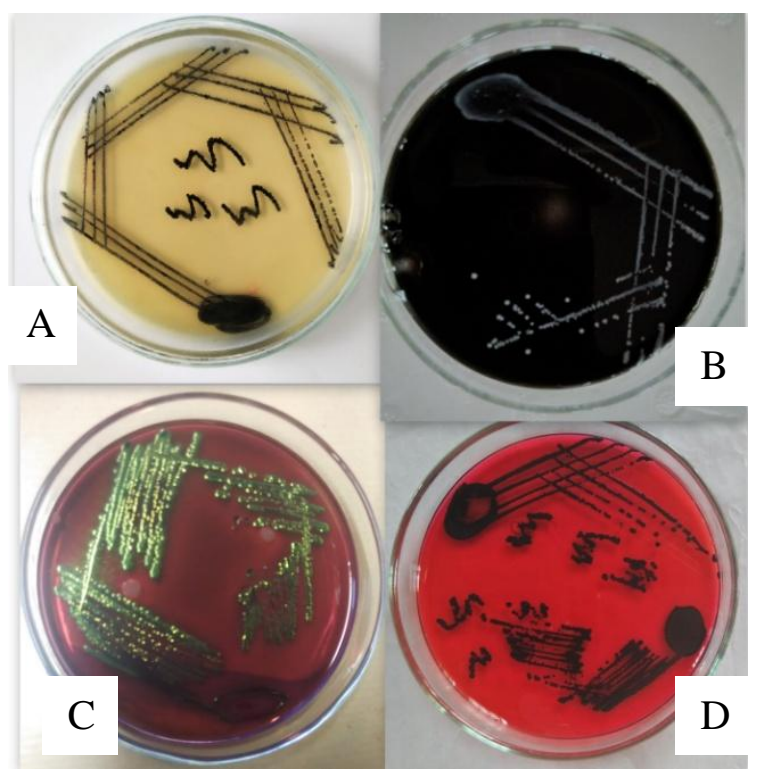

Recovery of pathogenic bacteria from meat products

The in-house prepared chicken products were artificially contaminated at $100 \mathrm{cfu} / \mathrm{g}$ and $1000 \mathrm{cfu} / \mathrm{g}$ with above mentioned food borne pathogens. The meat preparations were found positive for pathogenic bacteria like Staphylococcus aureus, Escherichia coli,
Salmonella spp. and Campylobacter jejuni by cultural and PCR method before cooking (Figs. 1-5). The results for detection of Staphylococcus aureus, Escherichia coli, Salmonella spp. and Campylobacter jejuni after artificial contamination, its presence before and after cooking treatments for chicken 65 , chilly chicken, chicken tandoori and grilled chicken are reported in table 4. 
The chicken 65 and chilly chicken were cooked by pan frying method of cooking; grilled chicken by electrical grilling method of cooking and chicken tandoori by tandoori oven method of cooking and were analyzed for the presence of food-borne pathogens but none of the samples were found to be positive at different inocula level i.e., $100 \mathrm{cfu} / \mathrm{g}$ and $1000 \mathrm{cfu} / \mathrm{g}$ of chicken products. The chicken products viz. Chicken 65, Chilly chicken, Grilled chicken and Tandoori chicken (Figure

1) were cooked to internal temperatures of $83.3^{\circ} \mathrm{C}, \quad 82.2^{\circ} \mathrm{C}, \quad 75.5^{\circ} \mathrm{C}$ and $74.3^{\circ} \mathrm{C}$ respectively, at this temperature food-borne pathogens Escherichia coli, Salmonella spp, Staphylococcus aureus and Campylobacter jejuni were not detected which indicates heat inactivation of organisms.

Thermal inactivation of food-borne pathogens in meat products is dependent on factors as fat content, texture and initial contamination level in food matrix (Jay, 2000: Juneja, 2001). The factors responsible for improper inactivation of food borne pathogen include non-isothermal cooking (Smelt and Brule, 2014), fat rich food, tissue adhered and deep seated microorganism in food matrix (Juneja et al., 2001). The above factors will lead to residual recovery of pathogenic bacteria even after heat treatment at high temperatures.

The different time temperature combinations optimized in study were in accordance with earlier reports by various researchers for thermal inactivation. Thermal destruction time for Escherichia coli were $55^{\circ} \mathrm{C}$ for 19.05 minutes and $70^{\circ} \mathrm{C}$ for 0.058 minutes (Murphy et al., 2004) and $60^{\circ} \mathrm{C}$ for 60 minutes, $65^{\circ} \mathrm{C}$ for 80 seconds and 60 seconds at $70^{\circ} \mathrm{C}$ (Charimba et al., 2010) respectively. For Salmonella spp., $55^{\circ} \mathrm{C}$ for 43.10 minutes and at $70^{\circ} \mathrm{C}$ for 0.096 minutes (Murphy et al., 2004) and at surface temperature $80^{\circ} \mathrm{C}$ for 1 minute (De jong et al., 2011). For Campylobacter jejuni, pan frying method for
2 minutes at $57^{\circ} \mathrm{C}$ temperature after 4 minutes (Sampers et al., 2010) and $80^{\circ} \mathrm{C}$ for 2.20 minutes on surface temperature (De jong et al., 2011). But in case of Staphylococcus aureus, the organism are heat labile and easily destructed whereas preformed staphylococcal enterotoxins are heat stable and resistant to proteolytic enzymes (Balaban and Rasooly, 2000). The proper cooking treatment and prevention of post processing contamination are important measures to control food-borne out breaks, as staphylococcal food poisoning involves the foods that involve frequent handling during product preparation (Loir et al., 2003).

The simulated study with different cooking practices on different chicken based meat products reached a core temperature of $72^{\circ} \mathrm{C}$ and above, ensures thermal destruction of all food borne pathogens. However, some reports suggest presence of food borne pathogen which could be of post processing contaminations from different sources like serving utensils, serving temperature, methods of storage and personal hygiene.

Thus present study, concludes that cooking practices followed by street food vendors and fast food outlets are safe when they reach the core temperature of $72^{\circ} \mathrm{C}$ and above. The awareness among the people regarding food borne pathogens and measures to prevent post processing contamination should be strengthened to safe guard public health.

\section{Acknowledgement}

Authors are thankful to Department of Livestock Products Technology (Meat Science), Department of Veterinary Public Health and Epidemiology, Madras Veterinary College, Chennaiand Tamil Nadu Veterinary and Animal Sciences University for the necessary facilities rendered and their support for this research work. 


\section{References}

ACMSF Report on Safe Cooking of Burgers Food Standards Agency, 2007. pp. 1-40

Antony, B., Scaria, B., Dias, M. and Pinto, H., 2009. Salmonella wien from gastroenteritis cases encountered in Mangalore, India: A report of 10 cases and review of the literature. Indian journal of medical sciences, 63(5): 195.

Bergsma, N.J., Fischer, A.R., Van Asselt, E.D., Zwietering, M.H. and De Jong, A.E., 2007. Consumer food preparation and its implication for survival of Campylobacter jejuni on chicken. British Food Journal, 109(7): 548-561.

Charimba, G., C. J. Hugo and Hugo. A, 2010. The growth, survival and thermal inactivation of Escherichia coli O157: $H 7$ in a traditional South African sausage. Meat science, 85 (1):89-95.

Darshana B. Bhaisare, D. Thyagarajan, R. Richard Churchil and Punniamurthy. N, 2014. Bacterial Pathogens in Chicken Meat: Review. International Journal of Life Sciences Research.2 (3): (1-7).

De Jong, A. E., E. D. Van Asselt, E. D., M. H. Zwietering, M. J. Nauta and R. de Jonge, 2012. Extreme heat resistance of food borne pathogens Campylobacter jejuni, Escherichia coli, and Salmonella typhimurium on chicken breast fillet during cooking. International journal of microbiology.

EFSA, 2014. The European Union summary report on trends and sources of zoonoses, zoonotic agents and foodborne outbreaks in 2012. EFSA. J., 12: $1-312$.

EFSA, ECDC. The European Union summary report on trends and sources of zoonoses, zoonotic agents and foodborne outbreaks in 2012. EFSA J., 2014. 1-312 (Available online: http://www.efsa.europa.eu/en/efsajourn $\mathrm{al} / \mathrm{pub} / 3547 . \mathrm{htm})$.
EU CRL for Listeria monocytogenes, 2008. Technical guidance document on shelflife studies for Listeira monocytogenes in ready-to-eat foods.

Fischer, A.R., De Jong, A.E., Van Asselt, E.D., De Jonge, R., Frewer, L.J. and Nauta, M.J., 2007. Food safety in the domestic environment: an interdisciplinary investigation of microbial hazards during food preparation. Risk Analysis, 27(4): 10651082.

Health education in food safety. Geneva, World Health Organization, 1988 (WHO/EHE/FOS/88.7).

ICMSF. 1983. International commission of microbiological specifications for foods. In: Elliott, R. P., Clark, D. S., Lewis, K. H., Lundbeck, H., Olson, J. C. andSimonsen, B. (eds) Microorganisms in Foods: Their Significance and Methods of Enumeration. Vol. 1. Toronto, ON: University of Toronto Press.

ISO 10272: 1995. Microbiology of food and animal feeding stuffs. Horizontal method for detection of thermotolerant Campylobacter. International Organization for Standardization.

ISO 16654:2001. Microbiology of food and animal feeding stuffs. Horizontal method for the detection of Escherichia coli O157. International Organization for Standardization.

ISO 6579: 2002 (E) $4^{\text {th }}$ ed. MicrobiologyGeneral guidance on methods for the detection of Salmonella, International Organization for Standardization, Geneva, Switzerland.

ISO 6888-1: 1999. Horizontal methods for enumeration of coagulase positive Staphylococci (Staphylococcus aureus and other species). Part 1 : Technique using Baird-Parker agar medium. International Organization for Standardization, Geneva, Switzerland. 
J.M. Jay Modern Food Microbiology (6th ed.), Aspen Publishers, Inc., Gaithersburg, Maryland (2000).

Juneja, V.K., Eblen, B.S. and Ransom, G.M., 2001. Thermal Inactivation of Salmonella spp. in Chicken Broth, Beef, Pork, Turkey, and Chicken: Determination of D- and Z- values. Journal of Food Science, 66(1): 146152.

Le Loir, Y., F. Baron and Gautier. M, 2003. Staphylococcus aureus and food poisoning. Genet. Mol. Res., 2 (1): 6376.

Murphy, R. Y., E. M. Martin, L. K. Duncan, B. L. Beard and J. A. Marcy, 2004. Thermal process validation for Escherichia coli O157: H7, Salmonella, and Listeria monocytogenes in ground turkey and beef products. J. Food Protect., 67(7): 1394-1402.

National Centre for Disease Control (NCDC), government of India, (2017). Foodborne diseases and food safety in India.

Phang, H.S., and Bruhn, C.M., 2011. Burger preparation: what consumers say and do in the home. Journal of Food Protection, 74(10), pp.1708-1716.
Prevention of Food Adulteration Rules, 1956 APPENDIX B Definitions and Standards of quality.

Redmond, E. C., and Griffith C. J., 2003. Consumer food handling in the home: a review of food safety studies. J. Food Protect., 66 (1): 130-161.

Roccato, A., M. Uyttendaele, V. Cibin, F. Barrucci, V. Cappa, P. Zavagnin and A. Ricci, A. 2015. Survival of Salmonella typhimurium in poultry-based meat preparations during grilling, frying and baking. Int. J. Food Microbiol., 197: 18.

Sampers, I., I. Habib, L. De Zutter, A. Dumoulin and M. Uyttendaele, 2010. Survival of Campylobacter spp. in poultry meat preparations subjected to freezing, refrigeration, minor salt concentration, and heat treatment. Int. J. Food Microbiol., 137 (2): 147-153.

Smelt, J.P.P.M., and Brul, S., 2014. Thermal inactivation of microorganisms. Critical reviews in food science and nutrition, 54(10): 1371-1385.

\section{How to cite this article:}

Mahantesh F. Meti and Appa Rao, V. 2017. Effectiveness of Cooking Methods on Presence of Food Borne Pathogens in Chicken based Meat Products. Int.J.Curr.Microbiol.App.Sci. 6(10): 39-49. doi: https://doi.org/10.20546/ijcmas.2017.610.006 